(c) American Dairy Science Association, 2004.

\title{
Accuracy of Foreign Dairy Bull Evaluations in Predicting United States Evaluations for Yield
}

\author{
R. L. Powell, A. H. Sanders, and H. D. Norman \\ Animal Improvement Programs Laboratory, ARS, USDA, Beltsville, MD 20705-2350
}

\section{ABSTRACT}

Combining foreign daughter data with domestic information in dairy bull genetic evaluations has been shown to improve prediction of future domestic evaluations for US bulls. This study focused on the accuracy of Interbull evaluations of bulls with only foreign daughters, in predicting the latest domestic evaluations (based on US daughters). August 2003 USDA evaluations based only on US daughters were matched with the most recent February or August Interbull evaluations without US daughters. A minimum reliability of at least $80 \%$ for yield and $70 \%$ for somatic cell score (SCS) was required in both evaluations. This provided pairs of evaluations based on different daughters (foreign or US) for 286 bulls (60 bulls for SCS). Mean Interbull reliabilities on the US scale were $88 \%$ for yield and $84 \%$ for SCS, and the mean US reliability for the current evaluations was $91 \%$ for yield and $80 \%$ for SCS. Correlations between the Interbull and domestic evaluations were $0.90,0.87,0.90$, and 0.87 for milk, fat, protein, and SCS respectively. Expected correlations were 0.89 for yield and 0.82 for SCS. Mean differences between the Interbull and current domestic evaluations were near zero. These foreign bulls had graduated from progeny test programs (selected for positive Mendelian sampling) before being marketed in the United States. Thus, parent average was a substantial underestimate of merit. The small average differences between evaluations from foreign and US daughters and high correlations indicate that Interbull evaluations based solely on foreign daughters are useful predictors of the US evaluations for yield and SCS, providing accuracy in agreement with reliabilities and much better estimates than the alternative, parent averages.

(Key words: Interbull, sire evaluation)

Abbreviation key: ASI = Australian selection index, $\mathbf{P A}=$ parent average, $\mathbf{R E L}=$ reliability .

Received December 31, 2003.

Accepted March 16, 2004.

Corresponding author: R. L. Powell; e-mail: rpowell@aipl. arsusda.gov.

\section{INTRODUCTION}

The inclusion of additional data from other countries has been shown to improve the accuracy of domestic dairy bull evaluations (Powell and Norman, 1998; Powell et al., 2000). Studies investigating the current quality of Interbull procedures also showed the value of including foreign data in dairy bull evaluations (Powell and Norman, 2000; Weigel and Powell, 2000). These 4 studies included mainly US bulls and did not evaluate the accuracy of foreign data alone. In the case of foreign bulls, the earliest information available for breeding decisions in the United States beyond pedigree usually comes from foreign daughters, and they often provide the large majority of data available later. Thus, an investigation of the accuracy of predicting future US evaluations using only foreign data is worthwhile.

McClintock et al. (2003) used the 2003 Australian selection index (ASI), which combined evaluations of milk, fat, and protein, for 62 bulls having at least 150 daughters to examine the predictive accuracy of Interbull evaluations from the year 2000 that included no Australian daughters. The Interbull evaluations were found to be reasonably good predictors of the later ASI. Overall, the Interbull evaluations tended to be optimistic. However, whereas the lowest-ranked bulls were overestimated, the top bulls were underestimated (regression of 2003 ASI on 2000 ASI from foreign daughters of 1.27).

The objectives of this study were to investigate 1) the usefulness of Interbull evaluations, based only on foreign daughters in predicting future US evaluations for yield and SCS, in comparison with concurrent US parent average (PA), and 2) the accuracy of Interbull reliability (REL) in indicating the precision of prediction of future US domestic genetic evaluations.

\section{MATERIALS AND METHODS}

Data were August 2003 US domestic evaluations (based only on US daughters) and earlier February or August Interbull evaluations from two times: 1) the latest evaluation without US daughters, included to assess accuracy with the maximal amount of independent foreign data, and 2) $3.5 \mathrm{yr}$ before the first US 
Table 1. Numbers of bulls and mean reliabilities (REL) of PTA and parent averages (PA) for yield traits and SCS.

\begin{tabular}{|c|c|c|c|c|}
\hline \multirow[b]{2}{*}{ Item } & \multirow[b]{2}{*}{ Bulls (No.) } & \multicolumn{3}{|c|}{ Mean REL (\%) } \\
\hline & & $\begin{array}{l}\text { Latest foreign } \\
\text { Interbull PTA }^{1}\end{array}$ & $\begin{array}{l}\text { Concurrent } \\
\text { US PA }\end{array}$ & $\begin{array}{l}\text { Current } \\
\text { US PTA }^{2}\end{array}$ \\
\hline All bulls & 286 & 88 & 42 & 91 \\
\hline Canadian bulls ${ }^{3}$ & 193 & 87 & 43 & 91 \\
\hline Dutch bulls ${ }^{3}$ & 43 & 89 & 41 & 94 \\
\hline Other bulls ${ }^{4}$ & 50 & 89 & 40 & 89 \\
\hline All bulls & 60 & 84 & 38 & 80 \\
\hline Canadian bulls ${ }^{3}$ & 33 & 85 & 39 & 80 \\
\hline Dutch bulls ${ }^{3}$ & 10 & 81 & 32 & 83 \\
\hline Other bulls ${ }^{5}$ & 17 & 82 & 39 & 79 \\
\hline
\end{tabular}

${ }^{1}$ Latest Interbull evaluation including no US daughters.

${ }^{2}$ The US domestic PTA for August 2003 (including no foreign daughters).

${ }^{3}$ Bulls with mostly Canadian or Dutch daughters in the latest foreign Interbull evaluation including no US daughters.

${ }^{4}$ Countries and numbers of bulls (in parentheses) were as follows: Australia (4); Belgium (1); Germany (12); Great Britain (7); France (14); Italy (5); New Zealand (3); Poland (1); Switzerland, Red Holstein (3).

${ }^{5}$ Countries and numbers of bulls (in parentheses) were as follows: Australia (2); Germany (2); Great Britain (1); France (6); Italy (4); Poland (1); Switzerland, Red Holstein (1).

evaluation, the approximate time semen was imported into the United States. Traits examined were milk, fat, protein, and SCS for Holstein bulls. The earliest Interbull evaluations were February 1995 for yield and August 2001 for SCS. Schaeffer (1994) provides a discussion of methods used in the Interbull evaluations. Selected evaluations were on the US scale, and bulls were included only when the Interbull REL was at least $80 \%$ for yield or $70 \%$ for SCS in analysis of that trait. The US PA from the same evaluation dates were also obtained. Methods used in US evaluations are described by VanRaden and Wiggans (1991). All evaluations and PA were converted to the current US base to allow the comparison of evaluations across time.

The August 2003 US (current domestic) evaluation was used to represent the "best" evaluations. Although REL was likely higher in the August 2003 official evaluation, the domestic evaluation was used because it provided a completely independent data source (daughters in the foreign-only evaluations are likely included in the August 2003 official evaluation). A REL of at least $80 \%$ for yield, or $70 \%$ for SCS in that trait analysis, was required in the current domestic evaluation for a bull to be included.

Interbull (foreign) evaluations and concurrent US PA were compared with the current domestic evaluations for milk, fat, protein, and SCS for difference, standard deviation of difference, and correlation. Expected correlation was the square root of the product of the mean REL. Actual correlations were all product-moment correlations. A majority of bulls included in the study had the greatest number of their foreign daughters in Canada. Analyses were repeated separately for Canadian bulls, Dutch bulls, and all other bulls to determine whether the source of foreign data influenced results. Country was determined by the country of most daughters included in the foreign evaluation.

Over the years covered by this study, changes to Interbull procedures have been made in estimated genetic correlations, birth year edits, reliability estimations, weighting of effective daughter contribution, and sire variance estimation. These refinements had more impact on individual bull evaluations than on overall rankings or correlations. The most significant change, incorporation of genetic correlations in August 1995, changed the set of top bulls, but the correlation with February 1995 was 0.99 . Based on Interbull evaluations spanning $9 \mathrm{yr}$, during which time methodology has changed, this study may present a conservative picture of the value of foreign evaluations relative to Interbull evaluations computed with current methodology. To determine whether these changes had an impact on the comparison of foreign PTA and concurrent PA, differences in foreign evaluations and PA from August 2003 evaluations were examined separately for each Interbull run.

\section{RESULTS AND DISCUSSION}

The number of bulls and mean REL are given in Table 1 . The number of bulls was considerably reduced for SCS due to the reduced time Interbull evaluations 
Table 2. Numbers of bulls having genetic evaluations for yield by date of latest Interbull evaluation that included no US daughters (foreign evaluation).

\begin{tabular}{|c|c|c|c|c|}
\hline $\begin{array}{l}\text { Date of latest } \\
\text { foreign } \\
\text { evaluation }\end{array}$ & All bulls & $\begin{array}{l}\text { Canadian } \\
\text { bulls }^{1}\end{array}$ & $\begin{array}{l}\text { Dutch } \\
\text { bulls }^{1}\end{array}$ & $\begin{array}{l}\text { Other } \\
\text { bulls }\end{array}$ \\
\hline February 1995 & 13 & 10 & 1 & 2 \\
\hline August & 4 & 4 & - & - \\
\hline February 1996 & 5 & 5 & - & - \\
\hline August & 5 & 4 & 1 & - \\
\hline February 1997 & 10 & 9 & - & 1 \\
\hline August & 18 & 10 & 6 & 2 \\
\hline February 1998 & 9 & 6 & 3 & - \\
\hline August & 9 & 7 & 1 & 1 \\
\hline February 1999 & 14 & 9 & 3 & 2 \\
\hline August & 23 & 19 & 3 & 1 \\
\hline February 2000 & 16 & 9 & 5 & 2 \\
\hline August & 12 & 10 & - & 2 \\
\hline February 2001 & 15 & 10 & 2 & 3 \\
\hline August & 16 & 11 & 3 & 2 \\
\hline February 2002 & 11 & 3 & 2 & 6 \\
\hline August $^{2}$ & 63 & 36 & 9 & 18 \\
\hline February 2003 & 3 & 2 & 1 & - \\
\hline August & 40 & 29 & 3 & 8 \\
\hline Total & 286 & 193 & 43 & 50 \\
\hline
\end{tabular}

${ }^{1}$ Bulls with mostly Canadian or Dutch daughters in the latest foreign Interbull evaluation including no US daughters.

${ }^{2}$ The US daughters for a larger number of bulls were included in the following evaluation (February 2003), making August 2002 the last Interbull evaluation including only foreign data due to a change in the requirements for inclusion of second (or additional) country data.

have been available. About two-thirds of the bulls (193) had most of their milking daughters in Canada at the time of their latest Interbull evaluation without US daughters. Of the other 93 bulls included for yield, 43 had most daughters in The Netherlands, 14 in France, and 12 in Germany. Due to limited observations per country, the 50 bulls from France, Germany, and 7 other countries were grouped together. Mean REL were very similar among the 3 bull groups. The Canadian bulls had slightly lower foreign REL for yield but higher for SCS. Canadian bulls also had slightly higher PA REL for yield, and PA REL for SCS was considerably higher than for Dutch bulls. This may reflect additional efforts in the earlier years to incorporate Canadian ancestral data, or more dams may have had US pedigree. The REL for current domestic PTA were highest for the Dutch bulls.

The number of bulls from the various Interbull runs is shown in Table 2. The two runs with the highest representation deserve explanations. From August 1995 through August 2002, Holstein bulls used in the United States following progeny testing in another country were required to have at least 75 daughters in at least 50 US herds before US data were included in Interbull evaluations. Beginning in November 2002, a US evaluation for these second-crop foreign bulls con- tributed to the Interbull evaluations if coded as official (i.e., all bulls with daughters in at least 10 US herds). Thus, for a large number of bulls, August 2002 was the latest Interbull evaluation without US daughters. In addition, a relatively large number of bulls had their latest foreign evaluation in August 2003 (the latest evaluation used in this study). These bulls have US daughters, and thus a current domestic evaluation, but those data are not included in the Interbull data because they did not meet the additional Interbull usability requirements. Primarily, this included bulls not coded as AI sampled in the United States. Although this results in a comparison of evaluations calculated at the same time, the contributing daughter groups in the August 2003 foreign and domestic evaluations are completely different for the bulls considered.

Mean differences between foreign PTA or concurrent US PA and current domestic PTA and SD of those differences are in presented in Table 3. Mean current domestic PTA were $126 \mathrm{~kg}$ for milk, $8.2 \mathrm{~kg}$ for fat, and $6.7 \mathrm{~kg}$ for protein, with SD of 381, 12.3, and 10.4, respectively. Mean differences were near zero for foreign PTA but were substantially negative for yield PA, indicating that PA was an underestimate of the later US PTA. Typically, PA are found to be overestimates of true merit (usually attributed to bias in dam PTA). However, bulls graduated from foreign sampling are expected to have highly positive Mendelian sampling deviation, thus overwhelming any positive bias in PA.

For SCS, mean current domestic PTA was 3.12 (SD = 0.24). Mean differences were the same between either the foreign PTA or concurrent US PA and current domestic PTA. The lack of bias may reflect the lack of emphasis on SCS in determining graduates from progeny testing in these data.

The SD of differences for foreign PTA were less than the SD of differences for PA, but still may seem slightly larger than typically observed for changes in evaluations over time. In interpreting those SD, it must be remembered that the foreign PTA and current domestic PTA include completely independent sets of daughters, whereas comparisons are typically between an early evaluation and a subsequent evaluation that includes the same early daughters.

Differences for foreign PTA, grouped by country of most daughters in the foreign evaluation are also in Table 3. They were close to zero for Canadian bulls. Dutch bulls showed a tendency for the foreign PTA to underestimate current domestic PTA, whereas the tendency for the other bulls was for overestimation. Mean differences were generally small, though some were statistically significant $(P<0.05)$. Mean SCS differences for Dutch and other bulls were near zero. Canadian bulls had higher current domestic PTA for SCS 
Table 3. Mean differences and SD of differences of the latest Interbull PTA including no US daughters (foreign PTA) or concurrent U.S. parent average (PA) with August, 2003 US domestic PTA for yield and SCS for all bulls or Canadian, ${ }^{1}$ Dutch,${ }^{1}$ and other bulls.

\begin{tabular}{|c|c|c|c|c|c|}
\hline \multirow[b]{2}{*}{$\begin{array}{l}\text { Country of most daughters } \\
\text { in foreign PTA }\end{array}$} & \multirow[b]{2}{*}{ Trait } & \multicolumn{2}{|c|}{ Foreign PTA } & \multicolumn{2}{|c|}{ Concurrent US PA } \\
\hline & & $\begin{array}{c}\text { Mean } \\
\text { difference }^{2}\end{array}$ & $\begin{array}{l}\text { SD of the } \\
\text { difference }\end{array}$ & $\begin{array}{c}\text { Mean } \\
\text { difference }^{3}\end{array}$ & $\begin{array}{l}\text { SD of the } \\
\text { difference }\end{array}$ \\
\hline All countries & $\begin{array}{l}\text { Milk }(\mathrm{kg}) \\
\text { Fat }(\mathrm{kg}) \\
\text { Protein }(\mathrm{kg}) \\
\text { SCS }\end{array}$ & $\begin{array}{c}7.8 \\
-0.2 \\
0.0 \\
-0.03\end{array}$ & $\begin{array}{c}167.1 \\
6.1 \\
4.7 \\
0.11\end{array}$ & $\begin{array}{c}-138.1 * * * \\
-3.4 * * * \\
-3.9 * * * \\
-0.03\end{array}$ & $\begin{array}{c}254.3 \\
10.0 \\
7.1 \\
0.19\end{array}$ \\
\hline Canada & $\begin{array}{l}\text { Milk }(\mathrm{kg}) \\
\text { Fat }(\mathrm{kg}) \\
\text { Protein }(\mathrm{kg}) \\
\text { SCS }\end{array}$ & $\begin{array}{l}2.5 \\
-0.5 \\
-0.2 \\
-0.04\end{array}$ & $\begin{array}{c}167.4 \\
6.2 \\
4.7 \\
0.12\end{array}$ & & \\
\hline The Netherlands & $\begin{array}{l}\text { Milk }(\mathrm{kg}) \\
\text { Fat }(\mathrm{kg}) \\
\text { Protein }(\mathrm{kg}) \\
\text { SCS }\end{array}$ & $\begin{array}{l}-19.0 \\
-1.5^{*} \\
-1.1 \\
-0.01\end{array}$ & $\begin{array}{c}131.2 \\
4.3 \\
3.9 \\
0.14\end{array}$ & & \\
\hline Other countries & $\begin{array}{l}\text { Milk }(\mathrm{kg}) \\
\text { Fat }(\mathrm{kg}) \\
\text { Protein }(\mathrm{kg}) \\
\text { SCS }\end{array}$ & $\begin{array}{r}51.4 \\
2.1^{*} \\
1.5^{*} \\
0.00\end{array}$ & $\begin{array}{c}187.3 \\
6.6 \\
4.9 \\
0.08\end{array}$ & & \\
\hline
\end{tabular}

$* P \leq 0.05$.

$* * * P \leq 0.001$.

${ }^{1}$ Bulls having the greatest number of their daughters contributing to the foreign PTA in Canada or The Netherlands.

${ }^{2}$ Foreign PTA - current US PTA.

${ }^{3} \mathrm{PA}$ - current US PTA.

(undesirable) than expected from the foreign data (i.e., merit was overestimated, though not significantly). The SD of differences were nearly identical between the Canadian bulls and the combination of the other 2 groups of bulls for all traits. However, separating the Dutch and other bulls showed lower SD for Dutch bulls and higher for other bulls for yield, and the reverse for SCS. The lower SD for yield traits of Dutch bulls was likely because they had the highest mean REL for both the latest foreign and current domestic evaluations.

Regressions of foreign PTA or concurrent PA, minus current domestic PTA, on time of the Interbull run were calculated. The regressions of foreign PTA were significantly positive for milk, fat, and protein $(12,0.4$, and $0.4 \mathrm{~kg} / \mathrm{yr}$, respectively), meaning that the more recent foreign evaluations were higher relative to the current domestic PTA than the earlier foreign evaluations. However, these regressions are not particularly large even when the effect is multiplied across a few years. When calculated separately for bulls with the most daughters in Canada, The Netherlands, or other countries, results were significant $(P<0.05)$ only for Canadian bulls. The trends for absolute differences were also small and significantly positive only for milk $(P<0.05)$ overall ( $5 \mathrm{~kg} / \mathrm{yr}$ ), and for the bulls from countries other than Canada or The Netherlands. No significant trend was found for SCS.
Relative to current domestic PTA, PA also increased significantly with time $(P<0.01)$ for milk and protein for Canadian and Dutch bulls, indicating that the degree to which PA underestimated current domestic PTA lessened over time. This is likely due to the closer agreement between more recent PA and the current PA used in calculating current PTA. The absolute difference between yield PA and current domestic PTA significantly decreased $(P<0.01)$ for Canadian and Dutch bulls, also likely due to the part-whole relationship increasing with time. No significant trend was found for SCS.

Correlations (Table 4) were essentially as expected for the yield traits but higher than expected for SCS. Expected correlations for Canadian, Dutch, and other bulls were similar, ranging from 0.88 to 0.91 for yield and 0.80 to 0.82 for SCS. Correlations for yield for Canadian bulls were lower than expected, especially for fat, whereas correlations for Dutch bulls were uniformly higher than expected values. For other bulls, correlations were above expected values for milk and protein and lower for fat. The higher yield correlations for the Dutch and other bulls relative to Canadian bulls might be related to their larger variation in foreign PTA $(20 \%$ more for Dutch bulls, 7\% more for others) and current domestic PTA (29\% for Dutch bulls, $26 \%$ more for others). This hypothesis was tested by limiting the bulls 
Table 4. Correlations of the latest Interbull PTA including no US daughters (foreign PTA) with August 2003 US domestic PTA for yield and SCS for all countries and Canadian, ${ }^{1}$ Dutch, ${ }^{1}$ and other bulls.

\begin{tabular}{llll}
\hline $\begin{array}{l}\text { Country of most daughters } \\
\text { in foreign PTA }\end{array}$ & Trait & Actual & Expected $^{2}$ \\
\hline All countries & Milk & 0.90 & 0.89 \\
& Fat & 0.87 & 0.89 \\
& Protein & 0.90 & 0.89 \\
SCS & 0.87 & 0.82 \\
Canada & Milk & 0.88 & 0.89 \\
& Fat & 0.84 & 0.89 \\
& Protein & 0.86 & 0.89 \\
The Netherlands & SCS & 0.86 & 0.82 \\
& Milk & 0.95 & 0.91 \\
& Fat & 0.95 & 0.91 \\
Other countries & Protein & 0.95 & 0.91 \\
& SCS & 0.80 & 0.82 \\
& Milk & 0.91 & 0.89 \\
& Fat & 0.86 & 0.89 \\
& Protein & 0.91 & 0.89 \\
& SCS & 0.95 & 0.80 \\
\hline
\end{tabular}

${ }^{1}$ Bulls having the greatest number of daughters contributing to the foreign PTA in Canada or The Netherlands.

${ }^{2}$ Expected correlation is the square root of the product of mean reliabilities for the foreign and US PTA.

to those having evaluations above the mean for each trait, thus mimicking a more uniformly selected group of bulls. The SD for foreign and domestic PTA were greatly reduced for this group as were the correlations between the Interbull and US evaluations. It is not unexpected that the Dutch and other bulls would be more diverse groups relative to the Canadian bulls that have a longer history of importation into the US and whose pedigrees and evaluation system are more familiar to US breeders.

Actual correlations for SCS were higher than expected for Canadian bulls and especially for the group of other bulls. VanRaden et al. (1997) reported a regression of SCS PTA on the corresponding estimate $3 \mathrm{yr}$ earlier of $1.16 \pm 0.10$. The change in PTA was $31 \%$ larger than expected. Conservative estimation of heritability could partly explain those findings and the low reliability estimates for the evaluations used in this study. Regardless of expectation, actual correlation for SCS for the group of other bulls is the highest among all traits and country-groups. The small ratio of bulls (17) to countries (7) may have an unknown impact.

A second part of the study examined Interbull evaluations of 64 bulls available $3.5 \mathrm{yr}$ before their first US evaluation. Those evaluations were assumed to reflect the information available at the time of semen importation that resulted in the US evaluation. Thus, they should represent the basis of the decision to use the bulls in the United States. Because Interbull evaluations for SCS began only in 2001, there were no SCS data to consider. The mean Interbull and concurrent
Table 5. Statistics on Interbull yield evaluations from $3.5 \mathrm{yr}$ prior to first US evaluation, concurrent US parent average (PA), and August 2003 (current) US PTA. ${ }^{1}$

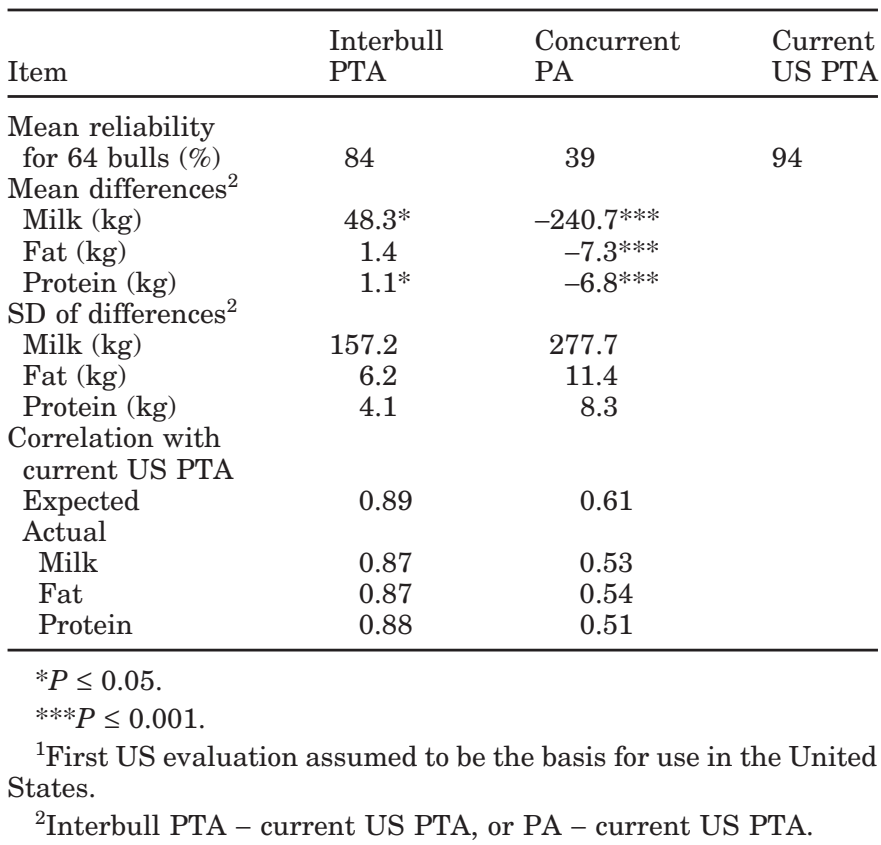

PA REL were lower (Table 5), as the yield evaluations were earlier in bulls' lives. The mean REL for the August 2003 US evaluations was higher, likely because the qualifying bulls were older. The Interbull evaluations at the time of importation tended to overestimate the current US evaluation and the concurrent US PA were even more of an underestimate than those from the time of the latest foreign evaluation (Table 2). For these same 64 bulls, overestimation by Interbull PTA was reduced to near zero with the latest Interbull evaluations without US daughters. Thus, although Table 2 shows an unbiased prediction, the Interbull evaluations did exaggerate yield merit by about $48 \mathrm{~kg}$ for milk and $1 \mathrm{~kg}$ for fat and protein (significantly for milk and protein, $P<0.05)$ at the time that the decision was made to use those bulls in the United States. This is in agreement with the observation by McClintock et al. (2003) that foreign evaluations overestimated later domestic evaluations.

Standard deviations of differences for estimated merit at time of initial use of these bulls in the United States (Table 5) were nearly the same as for the latest Interbull evaluation with only foreign daughters of the larger set of bulls. Actual correlations were slightly lower than the expected correlations.

\section{CONCLUSIONS}

Interbull evaluations based solely on foreign daughters are useful predictors of the US evaluations for yield 
and SCS, in particular, providing better estimates than the alternative, parent averages. Differences for the latest such Interbull evaluation averaged near zero for milk, fat, and protein for all bulls. In contrast, PA was a considerable underestimate due to the bulls in question being graduates of foreign progeny testing programs and selected for positive Mendelian sampling. Thus, PA are not a viable alternative to the Interbull evaluations from foreign daughters. The foreign evaluations ranked bulls essentially as well as expected based on the REL. Conclusions regarding Interbull evaluations available to select semen for US importation were generally the same, although these earlier evaluations were moderate overestimates of the later US PTA.

Interbull evaluations of Canadian, Dutch, and other foreign bulls showed similar predictive ability, and although the Interbull evaluations underestimated the US evaluations for Dutch bulls and overestimated them for the group of other bulls, the differences were not significant. Standard deviations of those differences were largest for the group of other bulls and least for Dutch bulls for yield but the reverse was true for SCS. Although mean REL for August 2003 SCS evaluations was higher for Dutch than for the other bulls, REL for foreign SCS evaluations was lower, and overall REL for SCS were considerably lower than for yield. Correlations with the August 2003 US evaluations were higher for Dutch or other bulls than for Canadian bulls, perhaps related to higher variation. These results clearly show that evaluations based on foreign data, specifically that from Interbull, are useful in selecting bulls for use in the United States.

\section{REFERENCES}

McClintock, A., K. Beard, and R. Poole. 2003. Interbull proofs are a reasonably unbiased prediction of future performance in Australia for imported bulls. Pages 169-170 in Proc. Interbull Annu. Mtg., Rome, Italy. Interbull No. 31, Uppsala, Sweden.

Powell, R. L., and H. D. Norman. 1998. Use of multinational data to improve national evaluations of Holstein bulls. J. Dairy Sci. $81: 2257-2263$.

Powell, R. L., and H. D. Norman. 2000. Impact of genetic correlations on accuracy of predicting future evaluations. Online. Available: http://www.adsa.org/jds/.

Powell, R. L., H. D. Norman, and G. Banos. 2000. Improving prediction of national evaluations by use of data from other countries. Online. Available: http://www.adsa.org/jds/.

Schaeffer, L. R. 1994. Multiple-country comparison of dairy sires. J. Dairy Sci. 77:2671-2678.

VanRaden, P. M., R. J. Starkenburg, and T. J. Lawlor. 1997. Stability of genetic evaluations for productive life, somatic cell score, and yield over time. J. Dairy Sci. 80(Suppl. 1):253.

VanRaden, P. M., and G. R. Wiggans. 1991. Derivation, calculation, and use of national animal model information. J. Dairy Sci. 74:2737-2746.

Weigel, K. A., and R. L. Powell. 2000. Retrospective analysis of the accuracy of conversion equations and multiple-trait, across-country evaluations of Holstein bulls used internationally. J. Dairy Sci. 83:1081-1088. 